\title{
Instruments used in the assessment of expectation toward a spine surgery: an integrative review
}

\author{
Instrumentos utilizados na avaliação da expectativa diante do \\ tratamento cirúrgico da coluna vertebral: revisão integrativa \\ Instrumentos utilizados en la evaluación de la expectación ante el \\ tratamiento quirúrgico de la columna vertebral: revisión integrativa
}

Eliane Nepomuceno ${ }^{1}$, Renata Cristina de Campos Pereira Silveira ${ }^{2}$, Carina Aparecida Marosti Dessotte ${ }^{2}$, Rejane Kiyomi Furuya $^{3}$, Eliana De Cássia Arantes ${ }^{4}$, Débora Cristine Prévide Teixeira da Cunha ${ }^{1}$, Rosana Aparecida Spadoti Dantas ${ }^{2}$

How to cite this article:

Nepomuceno E, Silveira RCCP, Dessotte CAM, Furuya RK, Arantes EC, Cunha DCPT, et al. Instruments used in the assessment of expectation toward a spine surgery: an integrative review. Rev Esc Enferm USP. 2016;50(4):656-663. DOI: http://dx.doi.org/10.1590/S0080-623420160000500017

${ }^{1}$ Universidade de São Paulo, Escola de Enfermagem de Ribeirão Preto, Programa de Pós-Graduação Interunidades, Ribeirão Preto, SP, Brazil.

${ }^{2}$ Universidade de São Paulo, Escola de Enfermagem de Ribeirão Preto, Departamento de Enfermagem Geral e Especializada, Ribeirão Preto, SP, Brazil.

${ }^{3}$ Instituto Federal do Paraná, Campus Londrina, Londrina, PR, Brazil.

${ }^{4}$ Universidade de São Paulo, Escola de Enfermagem de Ribeirão Preto, Programa de Pós-Graduação em Enfermagem Fundamental, Ribeirão Preto, SP, Brazil.

\begin{abstract}
Objective: To identify and describe the instruments used to assess patients' expectations toward spine surgery. Method: An integrative review was carried out in the databases PubMed, CINAHL, LILACS and PsycINFO. Results: A total of 4,402 publications were identified, of which 25 met the selection criteria. Of the studies selected, only three used tools that had confirmed validity and reliability to be applied; in five studies, clinical scores were used, and were modified for the assessment of patients' expectations, and in 17 studies the researchers developed scales without an adequate description of the method used for their development and validation. Conclusion: The assessment of patients' expectations has been methodologically conducted in different ways. Until the completion of this integrative review, only two valid and reliable instruments had been used in three of the selected studies.
\end{abstract}

\section{DESCRIPTORS}

Patients; Spinal Fusion; Spine; General Surgery; Review. 


\section{INTRODUCTION}

Degenerative diseases affecting the spine interfere with its functionality and cause compression of nerve roots creating a painful and debilitating condition ${ }^{(1-2)}$. They entail harm to the affected individuals who, due to the symptoms, limit their daily activities, and restrict ambulation and maintenance of some positions (e.g., standing) $)^{(3)}$.

Surgery is indicated when conservative treatment was not successful, that is, when the use of medications, change of lifestyle, and physical therapy, in a period greater than six months, did not result in the reduction of symptoms and in improved quality of life ${ }^{(4-5)}$. The surgical procedure removes hypertrophy resulting from structures consisting of bone and cartilage that have undergone degeneration, and releases the nerve roots ${ }^{(6)}$, aiming at improving quality of life and reducing symptoms. In general, patients expect that, after surgery, symptoms resolve completely, promoting life with no restrictions for their leisure, personal and professional activities. However, a successful surgical outcome depends on the time of disease evolution and progression of symptoms before surgery ${ }^{(7-8)}$.

Some researchers have called this optimistic feeling for the surgery outcome $\mathrm{e}^{(9-10)}$ as expectations toward surgical treatment. In our review, we adopt the definition of expectation as being the patients' assumption about the probability of something good or bad happening, or what they believe will happen, or want to happen ${ }^{(11)}$.

Expectations are recognized as an important component in the sub-clinical evaluation of patients who undergo spinal surgery. It is noteworthy that measuring expectations is particularly difficult among people with degenerative spine diseases, because in addition to the pain and neuromuscular impairment, there are striking features that can directly affect the clinical condition and the perspectives regarding treatment outcome. Such characteristics can be either intrinsic (disease progression time, emotional state, age, personality) and extrinsic (health team approach, support networks) to the individual who will undergo a surgery ${ }^{(10,12-14)}$.

The objective of this integrative review was to identify and describe the instruments used to assess patients' expectations toward spine surgical treatment.

Based on these results, nurses in the internal medicine area and researchers can choose instruments according to the psychometric characteristics presented: validity, reliability and practicality. With the use of a valid and accurate tool, professionals can assess patients' expectations preoperatively, and schedule care that can help them learn the real possibilities that surgery can bring to them, according to each individual's clinical condition.

\section{METHOD}

This integrative review was conducted through the following steps: 1) formulation of a guiding question; 2) literature search for studies regarding the proposed theme; 3) categorization of studies; 4) evaluation of the selected studies; 5) discussion and interpretation of results; and 6) knowledge synthesis ${ }^{(15)}$.

The guiding question was elaborated according to the PICO strategy (P-patient/population; I-intervention;
$\mathrm{C}$-comparison and $\mathrm{O}$-outcomes $)^{(16)}$. We considered $\mathrm{P}$ as $\mathrm{pa}^{-}$ tients undergoing an elective spine surgery; $\mathrm{I}$ as instruments that measure expectations toward a surgical treatment; $\mathrm{C}$ with no comparison; and $\mathrm{O}$ as the expectation construct of surgical treatment. Thus, the research question was: What are the instruments available in the literature used to measure patients' expectations toward spine surgical treatment?

The search strategy was based on the electronic databases: PubMed/MEDLINE of the National Library of Medicine, Cumulative Index to Nursing and Allied Health Literature (CINAHL), Latin American and Caribbean Center on Health Sciences Information (LILACS) and American Psychological Association (PsycINFO), in January 2016. To identify the primary studies performed with patients who underwent elective spine surgery, we used the controlled descriptor: 'orthopedics' and its synonyms. Regarding patients' expectations toward surgery, noncontrolled descriptors were used: "patient expectation", "patients expectations", "expectation", "expectations", "patients' expectation", "predictors". Noncontrolled descriptors were used because of the lack of a controlled descriptor for the construct expectation at the time of search. These terms were selected from articles published on the subject.

The descriptors were combined with the Boolean connectors AND and OR in Portuguese and English. Thus, the strategy for the search in the databases was: [orthopedics $O R$ orthopedic OR (orthopedic surgery) OR (orthopedic surgeries) OR (surgeries orthopedic) $O R$ (surgery orthopedic) $O R$ (spine surgery) $O R$ artbrodesis $O R$ artbrodeses $A N D$ (patient expectation) OR (patients expectations) OR expectation OR expectations OR (patients' expectation) $O R$ predictors], with necessary adaptations being made in each base.

The inclusion criteria adopted were: primary studies published in full evaluating adult and/or elderly patients' expectations towards spine surgical treatment, because of a degenerative disease, using tools, published in any language, regardless of the date of publication, and with a quantitative approach. Exclusion criteria were secondary studies and clinical guidelines, case studies, pilot study in preclinical stage; methodological studies; studies addressing urgent and emergency surgeries in the spine; studies evaluating expectation of quality of healthcare services or from healthcare professionals.

Following the search strategy, we proceeded with the reading of titles and abstracts by applying the selection criteria. Duplicated items among the bases and in the same database were excluded. Eligible articles were independently read in full by two reviewers, who extracted the previously defined data. A third reviewer solved possible remaining doubts. For data extraction, an instrument consisting of eight items was used: identification, objectives, methodological characteristics, instrument for assessing expectation, results related to expectation, limitation referred to by the authors, limitations referred to by the evaluator of the article, and conclusion. Once this step was completed, we conducted a manual search of the references of articles that had already been included in the sample, resulting in only one study. The composition of this review sample is presented in Figure 1, according to the PRISMA criteria ${ }^{(17)}$.

The studies were analyzed descriptively with the aim to answer our research question. 


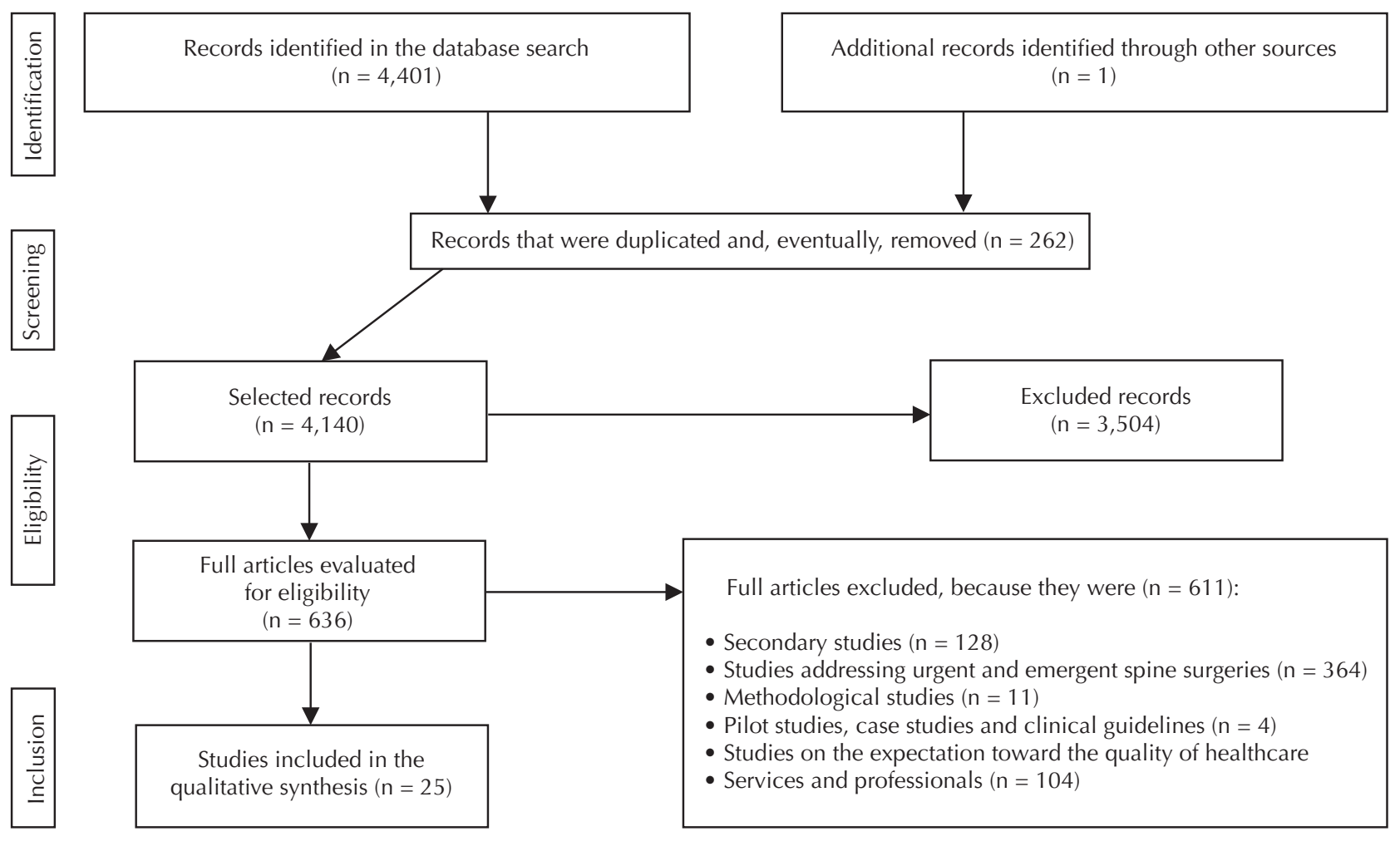

Figure 1 - Flowchart of the final sample of articles $(n=25)$ regarding the electronic search on the databases PubMed, LILACS, CINAHL and PsycINFO, according to the PRISMA criteria ${ }^{(17)}$. Ribeirão Preto, SP, Brazil, 2016.

\section{RESULTS}

The final sample consisted of 25 articles, of which only one was found through manual search ${ }^{(18)}$. The studies were published between 1998 and 2015 and, in general, publications on this subject increased in the last five years ${ }^{(9-10,14,19-30)}$. The methodological characteristics of the articles found are similar, with 16 observational studies ${ }^{(9-10,13-14,18-22,24,26,30-34)}$; six prospective cohorts ${ }^{(25,27-28,34,36-37)}$; one retrospective cohort $^{(38)}$, one quasi-experimental study ${ }^{(35)}$, and one experimental study ${ }^{(29)}$. The use of instruments occurred in the immediate preoperative period in 21 studies that assessed patients' expectations ${ }^{(10,14,18-19,20-26,28-33)}$, whereas in two studies it occurred when the patient received the indication of surgical treatment ${ }^{(9,27)}$, one study used them in the intermediate preoperative period $^{(13)}$; finally, one study completed the instrument after the patient underwent a spine surgery ${ }^{(34)}$.

Three categories were obtained according to the validity and reliability of the instrument that the authors used to measure patients' expectations toward spine surgery. The categories were: instruments already submitted to psychometric validation, modified clinical scores to assess patients' expectations and scales created by the authors themselves without an adequate description of the development methodology or any evidence of validation.

In the category of valid and reliable instruments, we found three studies ${ }^{(10,19,28)}$ using two instruments created by a group of American researchers: the Lumbar Spine Surgery Expectations Survey and the Expectations Survey, which have been recently published ${ }^{(39-40)}$. They can be self-administered, contain 20 items, and each item is answered with a five-point Likert scale that evaluates pain, muscle function, status, work, mental well-being, anticipation of the spine condition in the future. For both instruments, the total score ranges from 0 to 100 , and the higher the score, the greater the patients' expectations.

The first instrument, the Lumbar Spine Surgery Expectations Survey, created in 2013, aims to measure the expectations of the individual who will undergo a spine surgery, on the lower back region. The authors obtained good internal consistency (Cronbach's alpha $=0.92$ ) when they applied it to 420 individuals awaiting surgery. After surgery, the authors used the same items of the scale, but changed the original question focusing on expectation, changing it to satisfaction, with the results of the items assessed (pain, mental health, return to work). When the responses of the two evaluations were compared, they obtained a correlation coefficient of $86 \%$ (Cohen's kappa $=0.86$ ). Therefore, according to the authors, this instrument is valid and reliable and can measure expectations and, subsequently, satisfaction with the surgical treatment among patients who will undergo a lumbar spine surgery, in various diagnoses ${ }^{(39)}$.

The instrument Expectations Survey was created to measure patients' expectations toward cervical spine surgery, and was also published in 2013. Researchers in the study that created the instrument found good internal consistency (Cronbach's alpha $=0.93)$ after having applied it to 150 patients. After surgery, the same questionnaire, which had previously evaluated expectation, was modified to measure satisfaction with the treatment. The results obtained by 
comparing the two evaluations found an agreement coefficient of 90\% (Cohen's kappa $=0.90)$. Thus, the authors state that the instrument is valid and reliable, being able to measure the expectations of patients undergoing a spine surgery for various diagnosis, addressing clinical issues of physical and psychological nature ${ }^{(40)}$.

The second category describes studies using instruments already present in the literature, but that underwent some changes to be applied to measure patient's expectation toward surgery (Table 1 ). Three studies ${ }^{(9,20,30)}$ used the modified North American Spine Society (NASS) Lumbar Spine Outcome Assessment Instrument. The original instrument consisted of two questions, with eight items each. The first assessed patients' symptoms at the time of application and the second was about the main change expected by the patient after surgery ${ }^{(41)}$. The three studies made the same change in the original instrument to obtain information on how patients felt after surgery regarding their symptoms, addressed in the eight instrument items. Thus, the first question was reelaborated, and the second question was removed ${ }^{(9,20,30)}$.

The NASS Outcome Assessment Instrument measures the evolution outcome of all types of treatment for lumbar spine diseases regarding neurogenic symptoms, pain and disability. The authors obtained good internal consistency $($ Cronbach's alpha $=0.88)$ and test-retest reliability (Cohen's kappa $=0.95)^{(41)}$.

In another study ${ }^{(14)}$, the authors used the instrument Musculoskeletal Outcomes Data Evaluation and Management System (MODEMS) modified to assess patients' expectations toward lumbar spine surgery. The authors did not report the validity nor the reliability of the use of this instrument in patients with spinal problems. This instrument was created in 2004 by the American Academy of Orthopaedic Surgeons for patients with problems in the hip and knee. Its objective was to evaluate the results and management of the musculoskeletal system in general hospitals ${ }^{(42)}$.

The MODEMS scale contains six items, namely: pain relief, everyday activities, sleep comfort, return to work, physical exercise and lack of disability. The response options range from extremely likely to occur (5) to not at all likely to occur $(1)^{(42)}$. The original version obtained good internal consistency (Cronbach's alpha $=0.71$ ) and test-retest reliability (Cohen's kappa $=0.91$ ).

The last study (13) in this category used the instrument Schedule for the Evaluation of Individual Quality of Life-Direct Weight (SEIQOL-DW) modified. The authors inserted the expectation and satisfaction scale three months after spine surgery ${ }^{(13)}$, with the original instrument having the objective to evaluate patients' quality of life $\mathrm{e}^{(43)}$. The authors measured expectation following the same steps of the original instrument. Thus, they asked patients about five areas that were important to their satisfaction with the surgery, through a Visual Analogue Scale (VAS) (0-100) where patients marked their expectation intensity from two to 14 days before surgery. After surgery, the authors repeated the process, but measuring patient's satisfaction. The authors conducted a reliability test-retest (Cohen's kappa $=0.76$ ) with agreement of responses before surgery and three months later, explaining that the instrument was not meant to evaluate expectations, but satisfaction.

In the original article, good internal consistency (Cronbach's alpha $=0.71)$ and test-retest reliability were observed $(\text { Cohen's kappa }=0.71)^{(43)}$.

Chart 1 - Identification of modified clinical scores for evaluating patients' expectations - Ribeirão Preto, SP, Brazil, 2016.

\begin{tabular}{|c|c|c|c|}
\hline Study (country) & Instrument name & Expectation scoring method & Characteristics evaluated (Expectation) \\
\hline $\begin{array}{c}\text { Urban-Baeza et al., } \\
\left(\mathbf{2 0 1 5 ) ^ { ( 2 0 ) }}\right. \\
(\text { Mexico) }\end{array}$ & \multirow{3}{*}{$\begin{array}{c}\text { North American Spine } \\
\text { Society (NASS) Lumbar } \\
\text { Spine Outcome Assess- } \\
\text { ment Instrument }\end{array}$} & \multirow{3}{*}{$\begin{array}{c}\text { Five-point Likert scale: (5) } \\
\text { much better; (4) better; (3) } \\
\text { somewhat better; (2) un- } \\
\text { changed; (1) worse; (0) I don't } \\
\text { know. }\end{array}$} & \multirow{3}{*}{$\begin{array}{c}\text { Leg pain; Back pain; Walking capacity; Indepen- } \\
\text { dence in everyday activities; General physical } \\
\text { capacity (at home and at work); Sporting activities; } \\
\text { Frequency and quality of social contacts; Mental } \\
\text { well-being. }\end{array}$} \\
\hline $\begin{array}{l}\text { Vilà-Canet et al, } \\
(\mathbf{2 0 1 5})^{(30)} \\
\text { (Spain) }\end{array}$ & & & \\
\hline $\begin{array}{c}\text { Mannion et al., } \\
(\mathbf{2 0 0 9})^{(\mathbf{9})} \\
\text { (Switzerland) }\end{array}$ & & & \\
\hline $\begin{array}{l}\text { Soroceanu et al., } \\
(\mathbf{2 0 1 2})^{(14)} \\
(\text { Canada })\end{array}$ & $\begin{array}{l}\text { Musculoskeletal Out- } \\
\text { comes Data Evalua- } \\
\text { tion and Management } \\
\text { System (MODEMS) }\end{array}$ & $\begin{array}{l}\text { Five-point Likert scale: (5) ex- } \\
\text { tremely likely, (4) very likely, } \\
\text { (3) somewhat likely, (2) slightly } \\
\text { likely, (1) not at all likely. }\end{array}$ & $\begin{array}{l}\text { General pain; Everyday activities; Sleep; Work; } \\
\text { Exercise; Disability in the future. }\end{array}$ \\
\hline $\begin{array}{c}\text { Saban, Penckofer } \\
\left(^{(2007)^{(13)}}\right. \\
(\text { United States })\end{array}$ & $\begin{array}{c}\text { Schedule for the Evalua- } \\
\text { tion of Individual Qual- } \\
\text { ity of Life-Direct Weight } \\
\text { (SEIQOL-DW) }\end{array}$ & Visual Analogue Scale (VAS). & $\begin{array}{l}\text { Five domains selected by the individual interviewed } \\
\text { as the most important for his/her quality of life. }\end{array}$ \\
\hline
\end{tabular}

In the last category, we found the largest number of publications, with 17 studies that created scales to measure patient's expectation toward spine surgery. None of the studies described any type of face and content validation (Chart 2).

In four of the 17 articles in this category, the researchers used the VAS as a way to measure expectation ${ }^{(21-23,36)}$, seven

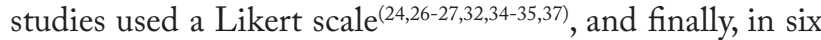
studies the researchers created closed-ended questions addressing patients' expectations toward surgery ${ }^{(18,25,29,31,33,38)}$.

Of these studies, in most cases, patients' expectation facing their main symptoms, such as pain, muscle function, and sensitivity ${ }^{(18,21-27,31-32,34,37)}$, was evaluated; others evaluated 
the general state of health, overall success of the surgery and recovery ${ }^{(23,29,31,33,35,36)}$; two studies evaluated return to work $^{(24,31)}$, and one assessed the social role ${ }^{(18)}$. Only one study mentioned that the questions asked had already been used in another study, but to assess patient's satisfaction after receiving a conservative treatment ${ }^{(44)}$.

Chart 2 - Instruments used, with no evaluation of psychometric properties - Ribeirão Preto, SP, Brazil, 2016.

\begin{tabular}{|c|c|c|}
\hline Study (country) & Evaluation scale & Characteristics evaluated (expectation) \\
\hline $\begin{array}{l}\text { Carr et al., } \\
(\mathbf{2 0 1 1})^{(21)} \\
\text { (United States) }^{\text {(U) }}\end{array}$ & Visual Analogue Scale (VAS). & Arm pain and neck pain. \\
\hline $\begin{array}{l}\text { Licina et al., } \\
\quad(2012)^{(22)} \\
\text { (Australia) }\end{array}$ & Visual Analogue Scale (VAS). & General pain. \\
\hline $\begin{array}{l}\text { Mcgregor; Dore; Mor- } \\
\text { ris (2013) } \\
\quad \text { (England) }\end{array}$ & Visual Analogue Scale (VAS). & $\begin{array}{c}\text { General health; leg pain; back pain; level of recovery } \\
\text { and overall surgery outcome. }\end{array}$ \\
\hline $\begin{array}{l}\text { Toyone et al., } \\
\quad(2005)^{(36)} \\
\quad(J a p a n)\end{array}$ & Visual Analogue Scale (VAS). & Overall success of surgery and surgical complications. \\
\hline $\begin{array}{l}\text { Lurie et al., } \\
(\mathbf{2 0 0 8})^{(27)} \\
\text { (United States) }\end{array}$ & $\begin{array}{l}\text { Five-point Likert scale: no chance, little chance, moder- } \\
\text { ate chance, great chance, certainly ( } 100 \% \text { chance). }\end{array}$ & $\begin{array}{l}\text { General symptoms, such as pain, stiffness, swelling, } \\
\text { numbness and weakness. Muscle function in activities } \\
\text { that were daily performed. }\end{array}$ \\
\hline $\begin{array}{l}\text { Ronnberg et al., } \\
(\text { (2007) })^{(34)} \\
\quad(\text { Island) }\end{array}$ & $\begin{array}{l}\text { Ordinal three-point Likert scale: (3) high; (2) medium; } \\
\text { (1) low. }\end{array}$ & Leg pain; back pain; muscle sensitivity and function. \\
\hline $\begin{array}{l}\text { Yee et al., (2008) })^{(32)} \\
\text { (Canada) }\end{array}$ & $\begin{array}{c}\text { Six-point Likert: (1) not at all likely, (2) slightly likely, (3) } \\
\text { somewhat likely, (4) highly likely, (5) extremely likely, } \\
\text { (6) not applicable. }\end{array}$ & $\begin{array}{l}\text { Leg pain; back pain; sensitivity; muscle function; } \\
\text { balance; instability; home activities; sleep; usual work } \\
\text { and practice of exercises and recreational activities. }\end{array}$ \\
\hline $\begin{array}{l}\text { Lattig et al., (2013) } \\
\text { (Germany) }\end{array}$ & $\begin{array}{l}\text { Five-point Likert scale, Patient versus Surgeon: } \\
\text { Expectation: (1) no pain, (2) little pain, (3) moderate } \\
\text { pain, (3) much pain, (4) severe pain. }\end{array}$ & $\begin{array}{l}\text { Back pain; leg pain; need for medication; sensitivity; leg } \\
\text { strength; back strength; work; leisure and sports. }\end{array}$ \\
\hline $\begin{array}{l}\text { Mcgregor, Hughes } \\
(\mathbf{2 0 0 2})^{(35)} \\
\text { (England) }\end{array}$ & $\begin{array}{l}\text { Six-point Likert scale: from (0) no improvement to (5) } \\
\text { best improvement possible. }\end{array}$ & General health status; general pain and life satisfaction. \\
\hline $\begin{array}{l}\text { Lurie et al., 2015 } \\
\quad \text { (United States) }\end{array}$ & $\begin{array}{l}\text { Five-point Likert scale: (1) no chance, (2) little chance, } \\
\text { (3) moderate chance, }(4) \text { great chance, (5) certainly } \\
\text { (100\% chance). }\end{array}$ & General pain; stiffness; numbness; weakness and work. \\
\hline $\begin{array}{l}\text { Sebaaly et al., 2014 } \\
\text { (France) }\end{array}$ & $\begin{array}{l}\text { Three-point Likert scale: no change }(-1) \text {, little } \\
\text { improvement }(0) \text {, very good improvement }(1) \text {. }\end{array}$ & $\begin{array}{l}\text { Back pain; radicular pain; sensitivity and motor } \\
\text { abilities. }\end{array}$ \\
\hline $\begin{array}{l}\text { Iversen et al.., } \\
(1998)^{(18)} \\
\text { (United States) }^{\text {(U) }}\end{array}$ & $\begin{array}{l}\text { Multiple choice closed- and open-ended questions that } \\
\text { was categorized later. }\end{array}$ & $\begin{array}{c}\text { Multiple choice closed-ended question: } \\
\text { General pain; physical ability; social role; } \\
\text { independence. } \\
\text { Open-ended questions: } \\
\text { How could surgery improve your life? } \\
\text { What did you feel you would be able to do after surgery } \\
\text { (activities)? }\end{array}$ \\
\hline $\begin{array}{l}\text { Lutz et al., (1999) })^{(33)} \\
\quad \text { (United States) }\end{array}$ & $\begin{array}{l}\text { Multiple choice closed-ended question already used in } \\
\text { a previous study }{ }^{(44)} \text {. }\end{array}$ & Recovery and general health. \\
\hline $\begin{array}{l}\text { Cobo Soriano et al., } \\
\qquad \begin{array}{l}(2010)^{(25)} \\
\text { (Spain) }\end{array}\end{array}$ & Multiple choice closed-ended question. & General pain; weakness; contractures; cramps. \\
\hline $\begin{array}{l}\text { De Groot; Boeke; } \\
\text { Passchier (1999) } \\
\text { (Netherlands) }\end{array}$ & Multiple choice closed-ended question. & Recovery time; leg and back pain; work. \\
\hline $\begin{array}{l}\text { Gepstein et al., } \\
(2006)^{(38)} \\
(\text { Israel })\end{array}$ & Multiple choice closed-ended question. & High or low expectation. \\
\hline $\begin{array}{l}\text { Engquist et al., } \\
(2015)^{(29)} \\
\text { (Sweden) }\end{array}$ & Multiple choice closed-ended question. & $\begin{array}{l}\text { Symptoms in general, such as: pain severity, disability } \\
\text { and muscle function. Recovery. }\end{array}$ \\
\hline
\end{tabular}




\section{DISCUSSION}

The subject 'patients' expectations toward spinal surgery' has currently become a focus of interest in studies published in the last five years. Thus, the present review was conducted to identify and describe the assessment tools of expectations, focused on this group of patients, used until January 2016. It is noteworthy that currently there are only two valid and reliable instruments to measure patients' expectation toward a spine surgical treatment. The tools identified in the literature, whose psychometric properties were recently published, are the Lumbar Spine Surgery Expectations Survey and the Expectations Survey ${ }^{(39-40)}$. This limited number of instruments generates a methodological barrier for researchers interested in evaluating the expectations of these patients regarding surgical treatment. In the coming years, we expect a greater number of studies with the aim to assess this construct, as well as validation for other languages and cultures of the two instruments found in three articles in this integrative review ${ }^{(10,19,28)}$.

The construction and validation of tools that assess subjective constructs have been considered complex and costly methodological studies ${ }^{(45)}$ to be developed, which may explain the small number of instruments found in our review. However, in general, we can recently see an increase in the number of published studies with a focus on presenting new measurement instruments to evaluate constructs, such as health-related quality of life ${ }^{(46)}$, compliance ${ }^{(47)}$, and knowledge ${ }^{(48)}$.

Unfortunately, among the other studies found, most of the instruments used did not provide an adequate description of their construction and validation process. While some of these instruments may be valid and reliable for assessing patient's expectations toward spine surgery, researchers of this topic should be concerned with the assessment of this important aspect of treatment so they can use measures for this evaluation that are increasingly valid and reliable. After all, when patients are realistically questioned about their expectations, it is possible to avoid utopic results, to narrow the gaps between the preoperative and postoperative periods, and to contribute to a better management of health status and each patient's needs ${ }^{(9,38)}$.

Researchers from countries that do not have instruments available to assess expectations have opted for the use of the VAS to measure how much the patient hopes to improve after spine surgery ${ }^{(21-23,36)}$. The use of the VAS has been shown to detect small changes over time, and clinically significant changes. Besides being easy to use, even for patients with low educational level and old age, it offers a more objective numeric result of the construct evaluated ${ }^{(49)}$.

Another important aspect when evaluating the use of instruments for subjective measures is the lack of consensus among researchers when using certain terms, such as scales, instruments and questionnaires, treating them equivalently. However, currently, researchers of the area have defined the scales as a term to describe only one item or category, and not a measure or a questionnaire. Instrument is another term that describes a device, which may be a collection of items of self-report, or a physical device. Finally, questionnaire is a term that is often used to describe a result reported by the patient ${ }^{(50)}$.

Ultimately, it is noteworthy that, in the assessment of patients' expectations toward spine surgery, healthcare professionals should consider that the expected results, i.e., patients' expectations, are also a result of the guidance provided by them in a clear and realistic way. They should also consider the patients' educational and cognitive level, beliefs and experiences that can provide information about the desires and fears facing the surgical outcome, the direct influence of the family and people that are closer to them, their emotional status, financial concerns, and quality of life $\mathrm{e}^{(9,12-14,38,49)}$. Therefore, along with the expectations, it is important to evaluate other constructs, such as: healthrelated quality of life, anxiety, depression, patient satisfaction with surgical outcome, and family's and health team's expectations. Thus, quality instruments are crucial for this.

\section{CONCLUSION}

The evaluation of patients' expectations concerning the surgical treatment of conditions that affect the spine has been methodologically conducted in different ways. Concern about the psychometric validation of the evaluation instrument of the construct expectation is recent. Until the completion of this integrative review, only one group of researchers had built and validated two instruments to assess patients' expectations toward surgical treatment. Subsequently, the results of their studies on the subject were published in three other articles, which were part of our review.

A valid and precise form of assessment of constructs, such as expectations, pain and compliance, is necessary to provide healthcare professionals with better planning of preoperative guidance for patients who will undergo a spine surgery.

\section{RESUMO}

Objetivo: Identificar e descrever os instrumentos usados para avaliar a expectativa dos pacientes diante do tratamento cirúrgico da coluna vertebral. Método: Revisão Integrativa realizada nas bases de dados PubMed, CINAHL, LILACS e PsycINFO. Resultados: Identificamos 4.402 publicações, das quais 25 atenderam aos critérios de seleção. Dos estudos selecionados, apenas em três os autores utilizaram instrumentos que possuíam validade e confiabilidade confirmadas para serem aplicados; em cinco estudos foram utilizados escores clínicos, modificados para a avaliação das expectativas dos pacientes, e em dezessete os pesquisadores elaboraram escalas sem adequada descrição do método usado para o seu desenvolvimento e validação. Conclusão: A avaliação das expectativas dos pacientes tem sido metodologicamente conduzida de diferentes maneiras. Até a finalização desta revisão integrativa, apenas dois instrumentos, válidos e confiáveis, haviam sido utilizados em três dos estudos selecionados.

\section{DESCRITORES}

Pacientes; Fusão Vertebral; Coluna Vertebral; Cirurgia Geral; Revisão. 


\section{RESUMEN}

Objetivo: Identificar y describir los instrumentos utilizados para evaluar la expectación de los pacientes ante el tratamiento quirúrgico de la columna vertebral. Método: Revisión Integrativa llevada a cabo en las bases de datos PubMed, CINAHL, LILACS y PsycINFO. Resultados: Identificamos 4.402 publicaciones, de las que 25 atendieron los criterios de selección. De los estudios seleccionados, solo en tres los autores utilizaron instrumentos que tenían validez y confiabilidad confirmadas para aplicarse; en cinco estudios, fueron utilizados scores clínicos, modificados para la evaluación de las expectaciones de los pacientes; y, en diecisiete, los investigadores diseñaron escalas sin la adecuada descripción del método utilizado para su desarrollo y validación. Conclusión: La evaluación de las expectaciones de los pacientes está siendo metodológicamente conducida de distintas maneras. Hasta la finalización de esta revisión integrativa, solo dos instrumentos, válidos y confiables, se habían utilizado en tres de los estudios seleccionados.

\section{DESCRIPTORES}

Pacientes; Fusión Vertebral; Columna Vertebral; Cirugía General; Revisión.

\section{REFERENCES}

1. Fontal JAB, Granell JB, Olmo JG, Busquets RR, Prats FP, Leal CV. Evaluation of health-related quality of life in patients candidate for spine and other musculoskeletal surgery. Eur Spine J. 2013;22(5):1002-9.

2. Jacob Filho W, Kikuchi EL. Geriatria e gerontologia São Paulo: Elsevier; 2011.

3. Oliver J, Middledith A. Anatomia funcional da coluna vertebral. Rio de Janeiro: Revinter; 1998.

4. Genevay S, Atlas S. Lumbar spinal stenosis. Best Pract Res Clin Rheumatol. 2010;24(2):253-65.

5. Weinstein JN, Tosteson TD, Lurie JD, Tosteson AN, Blood E, Hanscom B, et al. Surgical versus Norsurgical therapy for lumbar spinal stenosis. N Engl J Med. 2008;358(8):794-810.

6. Den Boer JJ, Oostendorp RA, Beems T, Munneke M, Oerlemans M, Evers AW. A Systematic review of bio-psychosocial risk factors for an unfavourable outcome after lumbar disc surgery. Eur Spine J. 2006;15(5):527-36.

7. Sirvanci M, Bhatia M, Ganiyusufoglu KA, Duran C, Tezer M, Ozturk C, et al. Degenerative lumbar spinal stenosis: correlation with Oswestry Disability Index and MR imaging. Eur Spine J. 2008;17(5):679-85.

8. Valesin Filho ES, Ueno FH, Cabral LTB, Yonezaki AM, Nicolau RJ, Rodrigues LMR. Estudo prospectivo de avaliação de dor e incapacidade de pacientes operados de estenose de canal lombar com seguimento mínimo de dois anos. Coluna. 2009;8(4):390-4.

9. Mannion AF, Junge A, Elfering A, Dvorak J, Porchet F, Grob D. Great expectations: really the novel predictor of outcome after spinal surgery? Spine (Phila Pa 1976). 2009;34(15):1590-9.

10. Mancuso CA, Duculan R, Stal M, Girardi FP. Patients' expectations of cervical spine surgery. Spine (Phila Pa 1976). 2014;39(14):1157-62.

11. Leventhal L. The role of understanding customer expectations in aged care. Int J Health Care Qual Assur. 2008;21(1):50-9.

12. Ingadottir B, Johansson Stark A, Leino-Kilpi H, Sigurdardottir AK, Valkeapää K, Unosson M. The fulfilment of knowledge expectations during the perioperative period of patients undergoing knee arthroplasty: a Nordic perspective. J Clin Nurs. 2014;23(19-20):2896-908.

13. Saban KL, Penckofer SM. Patient expectations of quality of life following lumbar spinal surgery. J Neurosci Nurs. 2007;39(3):180-9.

14. Soroceanu A, Ching A, Abdu W, McGuire K. Relationship between preoperative expectations, satisfaction, and functional outcomes in patients undergoing lumbar and cervical spine surgery. Spine (Phila Pa 1976). 2012;37(2):E103-8.

15. Ganong, LH. Integrative reviews of nursing research. Res Nurs Health. 1987;10(1):1-11.

16. Nobre MR, Bernardo WM, Jatene FB. Evidence based clinical practice. Part 1-well structured clinical questions. Rev Assoc Med Bras 2003;49(4):445-9.

17. Moher D, Liberati A, Tetzlaff J, Altman DG; PRISMA Group. Preferred reporting items for systematic reviews and meta-analyses: the PRISMA statement. PLoS Med. 2009;6(7): e1000097.

18. Iversen MD, Daltroy LH, Fossel AH, Katz JN. The prognostic importance of patient pre-operative expectations of surgery for lumbar spinal stenosis. Patient Educ Couns. 1998;34(2):169-78.

19. Mancuso CA, Duculan R, Stal M, Girardi FP. Patients' expectations of lumbar spine surgery. Eur Spine J. 2015;24(11):2362-9.

20. Urban-Baeza A, Zárate-Kalfópulos B, Romero-Vargas S, Obil-Chavarría C, Brenes-Rojas L, Reyes-Sánchez A. Influence of depression symptoms on patient expectations and clinical outcomes in the surgical management of spinal stenosis. J Neurosurg Spine. 2015;22(1):75-9.

21. Carr FA, Healy KM, Villavicencio AT, Nelson EL, Mason A, Burneikiene S, et al. Effect on clinical outcomes of patient pain expectancies and preoperative Mental Component Summary scores from the 36-Item Short Form Health Survey following anterior cervical discectomy and fusion. J Neurosurg Spine. 2011;15(5):486-90.

22. Licina P, Johnston M, Ewing L, Pearcy M. Patient expectations, outcomes and satisfaction: related, relevant or redundant? Evid Based Spine Care J. 2012;3(4):13-9.

23. Mcgregor AH, Dore CJ, Morris TP. An exploration of patients' expectation of and satisfaction with surgical outcome. Eur Spine J. 2013;22(12):2836-44

24. Lattig F, Fekete TF, O’Riordan D, Kleinstück FS, Jeszenszky D, Porchet F, et al. A Comparison of Patient and Surgeon Preoperative Expectations of Spinal Surgery. Spine (Phila Pa 1976). 2013;38(12):1040-8.

25. Cobo Soriano J, Revuelta MR, Fuente MF, Díaz IC, Ureña PM, Meneses RD. Predictors of outcome after decompressive lumbar surgery and instrumented posterolateral fusion. Eur Spine J. 2010;19(11):1841-8. 
26. Sebaaly A, Samaha E, Basma J, Raffoul L, Okais N, Moussa R, et al. Évaluation de la douleur, qualité de vie et satisfaction des patients Libanais. J Med Liban. 2014;62(4):187-90.

27. Lurie JD, Berven SH, Gibson-Chambers J, Tosteson T, Tosteson A, Hu SS, et al. Patient preferences and expectations for care: determinants in patients with lumbar intervertebral disc herniation. Spine (Phila Pa 1976). 2008;33(24):2663-8.

28. Mancuso CA, Duculan R, Cammisa FP, Sama AA, Hughes AP, Lebl DR, et al. Proportion of expectations fulfilled: a new method to report patient-centered outcomes of spine surgery. Spine (Phila Pa 1976). 2015;41(11):963-70.

29. Engquist M, Löfgren H, Öberg B, Holtz A, Peolsson A, Söderlund A, et al. Factors Affecting the outcome of surgical versus nonsurgical treatment of cervical radiculopathy: a randomized, controlled study. Spine (Phila Pa 1976). 2015;40(20):1553-63.

30. Vilà-Canet G, Covaro A, de Frutos AG, Ubierna MT, Rodríguez-Alabau S, Mojal S, et al. Do surgical expectations change depending on first time surgery or reoperation? A prospective cohort study in lumbar spine surgery. Eur Spine J. 2015;24(11):2370-6.

31. de Groot KI, Boeke S, Passchier J. Preoperative expectations of pain and recovery in relation to postoperative disappointment in patients undergoing lumbar surgery. Med Care. 1999;37(2):149-56.

32. Yee A, Adjei N, Do J, Ford M, Finkelstein J. Do patient expectations of spinal surgery relate to functional outcome? Clin Orthop Relat Res. 2008;466(5):1154-61.

33. Lutz GK, Butzlaff ME, Atlas SJ, Keller RB, Singer DE, Deyo RA. The relation between expectations and outcomes in Surgery for Sciatica. J Gen Intern Med. 1999;14(12):740-4.

34. Rönnberg K, Lind B, Zoëga B, Halldin K, Gellerstedt M, Brisby H. Patients' satisfaction with provided care/information and expectations on clinical outcome after lumbar disc herniation surgery. Spine (Phila Pa 1976). 2007;32(2):256-61.

35. McGregor AH, Hughes SP. The evaluation of the surgical management of nerve root compression in patients with low back pain: Part 2. Patient expectations and satisfaction. Spine (Phila Pa 1976). 2002;27(13):1471-6.

36. Toyone T, Tanaka T, Kato D, Kaneyama R, Otsuka M. expectations and satisfaction in lumbar spine surgery. Spine (Phila Pa 1976). 2005;30(23):2689-94.

37. Lurie JD, Henderson ER, McDonough CM, Berven SH, Scherer EA, Tosteson TD, et al. The effect of expectations on treatment outcome for lumbar intervertebral disc herniation. Spine (Phila Pa 1976). 2015;41(9):803-9.

38. Gepstein R, Arinzon Z, Adunsky A, Folman Y. Decompression surgery for lumbar spinal stenosis in the elderly: preoperative expectations and postoperative satisfaction. Spinal Cord. 2006;44(7):427-31.

39. Mancuso CA, Cammisa FP, Sama AA, Hughes AP, Girardi FP. Development of an expectations survey for patients undergoing cervical spine surgery. Spine (Phila Pa 1976). 2013;38(9):718-25.

40. Mancuso CA, Cammisa FP, Sama AA, Hughes AP, Ghomrawi HMK, Girardi FP. Development and testing of an expectations survey for patients undergoing lumbar spine surgery. J Bone Joint Surg Am. 2013;95(19):1793-800.

41. Daltroy LH, Cats-Baril WL, Katz JN, Fossel AH, Liang MH. The North American spine society lumbar spine outcome assessment Instrument: reliability and validity tests. Spine (Phila Pa 1976). 1996;21(6):741-9.

42. Saleh KJ, Bershadsky B, Cheng E, Kane R. Lessons learned from the hip and knee musculoskeletal outcomes data evaluation and management system. Clin Orthop Relat Res. 2004;(429):272-8.

43. O'Boyle CA, McGee H, Hickey A, O'Malley K, Joyce CR. Individual quality of life in patients undergoing hip replacement. Lancet. 1992;339(8801):1088-91.

44. Cherkin DC, Deyo RA, Street JH, Barlow W. Predicting poor outcomes for back pain seen in primary care using patients' own criteria. Spine (Phila Pa 1976). 1996;21(24):2900-7.

45. Pasquali L. Psychometrics. Rev Esc Enferm USP [Internet]. 2009 [cited 2016 Feb 29]; 43(n.spe):992-9. Available from: http://www.scielo. br/pdf/reeusp/v43nspe/en_a02v43ns.pdf

46. Azuaga TL, Cavali PTM, Risso Neto MI, Zuiani GR, Pasqualini W, Veiga IG, et al. Tradução e adaptação transcultural para a língua portuguesa do "Swiss Spinal Stenosis Questionnaire". Coluna. 2013;12(1):36-41.

47. Rodrigues MTP, Moreira TMM, Andrade DF. Elaboration and validation of instrument to assess adherence to hypertension treatment. Rev Saúde Pública [Internet]. 2014 [cited 2016 May 25];48(2):232-40. Available from: http://www.scielo.br/pdf/rsp/v48n2/en_0034-8910rsp-48-2-0232.pdf

48. Bonin CDB, Santos RZ, Ghisi GLM, Vieira AM, Amboni R, Benetti M. Construção e validação do questionário de conhecimentos para pacientes com insuficiência cardíaca. Arq Bras Cardiol. 2014;102(4):364-73.

49. Mayo NE. ISOQOL Dictionary of Quality of Life and Health Outcomes Measurement. Québec: Reseau de Recherche em Santé des Populations du Quebec; 2015.

50. Falavigna A, Righesso Neto O, Teles AR. Avaliação clínica e funcional no pré-operatório de doenças degenerativas da coluna vertebral. Coluna. 2009;8(3):245-53. 